\title{
Imagem e aporia no Sofista de Platão
}

\author{
MARCELO P. MARQUES \\ Departamento de Filosofia \\ Faculdade de Filosofia e Ciências Humanas \\ Universidade Federal de Minas Gerais
}

\begin{abstract}
RESUMO: É no contexto da série de aporias relativas à possibilidade de dizer o não-ser, numa perspectiva eleata, aporias derivadas da posição inicial do problema da produção de imagens, que o Estrangeiro e Teeteto formulam uma definição da imagem que, por sua vez, se apresenta como uma aporia do não-ser. Meu propósito é compreender o problema da imagem no Sofista articulando-o aos temas da produção (dimensão antropológica) e da aporia (dimensão lógicoontológica).
\end{abstract}

PALAVRAS-CHAVE: Platão; sofista; imagem; aporia.

Precisamos da miragem para sermos capazes de atravessar o deserto (Provérbio árabe').

Depois de tê-lo cercado nos gêneros da antilogia e da purificação, nos quais o sofista é surpreendentemente visto como o nobre refutador, aquele que purifica a alma das opiniões que fazem obstáculo ao conhecimento, o Estrangeiro de Eléia propõe uma mudança de paradigma, na caça que empreende ao sofista (a partir de 233D3). Mas ele não abandona o antilégein definitivamente; o que ele faz é extrair desse paradigma as conseqüências que favorecem o desenvolvimento da pesquisa. E ele o faz entrelaçando contradizer e aparecer (233A8-9; 233B1-2; 233C1-2; 233C6; 233C10-11), através de sucessivas reformulações da idéia inicial: "produzir contraditores" (poiê̂n antilogikoús) (232B12). Essas reformulações, a cada vez, revelam novas nuanças, até que a arte da contradição do sofista aparece como a forma de jogo mais cheia de arte e a mais agradável (tekhnikóteron ... khariésteron eídos): a mimética (tò mimetikón).

Acompanhando a passagem do tema da antilogia ao tema da aporia, pretendo analisar o processo de produção da imagem e de enfeitiçamento pela mesma; em seguida, passarei às aporias do não-ser, onde será o caso de analisar o estatuto ontológico da imagem assim como o problema do discurso falso.

No plano geral, pretendo mostrar que, em Platão, o problema da imagem associa-se intimamente ao da aporia; que a imagem é utilizada para expressar, comentar e trabalhar as aporias da investigação dialética. Pretendo ainda destacar que o ser da imagem é aporético 
nele mesmo e que, por isso, ele pode ser utilizado como ponto de partida para se pensar questões fundamentais da ontologia platônica. No Sofista, trata-se do ser da imagem, enquanto aporia do ser e do não-ser, implicada na tarefa de dizer o não-ser.

\section{Produção}

O sentido do desenvolvimento da argumentação, que leva do antilégein ao mimeisthai, é o seguinte: o Estrangeiro passa do "produzir homens capazes de contestar e de contradizer" (poieîn amphibetetikoús) (232D2) ao "saber não apenas dizer mas também contradizer todas as coisas", e daí ao "saber produzir e fazer todas as coisas com uma só arte" (epístasthai ... mè légein med’ antilégein ... poieîn kaì drân ... sunápanta prágmata ... miâ tékhne) (233D910). Ao explicitarmos a relação entre "produzir homens" e "produzir coisas" torna-se manifesta uma certa compreensão do problema da alteridade que se aplica diferentemente aos homens e às coisas, mas que exige uma formulação discursiva que levará o debate dialético necessariamente ao plano das formas inteligíveis e, neste, ao gênero inteligível do outro (tò héteron).

A arte sofística da contradição (antilogía), enquanto poder de agir sobre o outro, não funcionaria bem se os sofistas não aparecessem (ephaínonto) aos jovens ouvintes como sendo capazes de contradizer corretamente, ou se, mesmo aparecendo (phainómenoi) como tais, eles não fossem capazes de parecer (edókoun) ser, pela contestação (dià tèn amphisbétesin), mais inteligentes e sábios do que são realmente. O que, finalmente, não é mais do que um tipo de ciência da aparência (anapéphantai ... dokhastikèn epistémen) (233C10-11). Para produzir a aparência de tudo saber, pois seriam capazes de contradizer tudo, eles têm que produzir, através do discurso, as coisas que contradizem. A representação das coisas, indiferente à sua participação no ser, é como uma segunda produção destas mesmas coisas. É assim que, de supostos contraditores que eram e de produtores de homens capazes de contradizer sobre todas as coisas, eles passam a ser vistos como produtores de todas as coisas.

Essa produção é o jogo da imitação (tò mimetikón) (234A7; B1-2) e as coisas que o sofista fabrica são imitações e homônimos, isto é, imagens dos seres (234B6-7 - mimémata kai honónuma tôn ónton apergazómenos). A caça ao sofista atinge assim, segundo as palavras de Teeteto, "sua forma mais completa e mais variada, reunindo tudo numa só unidade" (234B3-4 - pámpoly gàr eírekas eídos eis hen pánta sullabòn kaì skhedòn poikilótaton), unidade que finalmente dará conta da multiplicidade e da variedade inerentes ao gênero em questão, o gênero da sofística. Esta unidade será conferida pelo gênero da produção de imagens (eidolopoiiké), objeto da última divisão.

A mimética dos sofistas é análoga à dos pintores na medida em que ambas produzem imagens, estas 'coisas outras' que retiram sua potência, sua eficácia persuasiva do fato de sua semelhança com as coisas reais, o que faz com que os produtos miméticos sejam duplamente interessantes. Por um lado, devido ao perigo (lógico e ético) que implicam, pois eles foram reconhecidos como fazendo parte deste gênero escorregadio que faz com que tomemos uma coisa pela outra: a semelhança (231A6-B1); por outro lado, devido justamente ao seu caráter intrinsecamente heterológico. O que define os produtos miméticos é o fato de 
serem "outros que" e ao mesmo tempo "semelhantes a" aquilo com relação a que são outros. É a semelhança daquilo que é outro que nos permitirá continuar com a caça ao sofista através de seu princípio último de inteligibilidade que é a alteridade².

Com a arte de pintar, qualquer um será capaz de fazer crer que ele pode realizar efetivamente tudo o que deseja produzir (hótiper àn boulethê drân) (234B5-10). Do ponto de vista antropológico, a imagem atua através do desejo. A imagem com seu poder de enfeitiçamento promete satisfazer (todos) os desejos e aspirações daqueles que lhe estão submetidos. A mera (re)presença da coisa, tornada magicamente possível pela imagem (visual ou verbal) atua sobre os homens que desejam sempre mais ser, no sentido da afirmação de si mesmos; homens que desejam ter mais poder sobre o real e sobre os outros homens. O desejo desencadeado pela imagem pode ser tanto desejo de ser, como desejo do ser, desejo esse que é (humanamente) suscetível de enganar-se sobre seu rumo, seu destino, isto é, sobre aquilo que é efetivamente o melhor para ele próprio, podendo assim transformar-se em paixão ou submissão aos homens e às coisas. A força e o perigo da imagem residem nessa sua potência de promessa. A imagem promete mais realidade àquele que se submete a ela, ao que se apaixona por ela.

Mas é importante ressaltar que, atuando no plano do desejo, a imagem pode trabalhar, ao mesmo tempo, a favor do movimento do pensamento. Devemos reconhecer o desejo, em Platão, como uma força que atravessa os três níveis da alma (Canto-Sperber, 1997, p.1146-1156). Como nos mostra a República, Eros é a força propulsora da alma, com sua razão, com seu ardor e com seu apetite. Como nos ensina o Banquete, Eros atravessa e propulsiona a alma no sentido da realização de sua verdade, na medida em que ele se reconhece progressivamente como desejo de saber e desejo de ser (Frère, 1981). O filósofo conta com a capacidade da alma de potencializar o desejo. Uma passagem decisiva, que mostra como a imagem pode ser utilizada a favor do conhecimento, é a da "linha dividida" da República (509D-511E), onde a noção de imagem é utilizada de modo relativo e flexível, não se restringindo à primeira seção. De fato, ao falar da primeira seção, Sócrates refere-se às imagens (eikónes) e às coisas (seres vivos, objetos fabricados) das quais elas são as imagens. Imagens, nesta passagem, são as sombras, as aparições (phantásmata) sobre as águas e sobre tudo aquilo que tem uma consistência compacta, lisa e brilhante, e todas as coisas deste tipo (509E-510A). A seção seguinte é posta como o domínio dos objetos aos quais se assemelham as imagens da seção anterior, seus originais. Entretanto, sabemos que estes objetos não nos permitem uma experiência tão mais clara, em termos de compreensão e inteligência; eles são mais claros que suas imagens, mas ainda causam estados de alma (pathémata) confusos, relativamente obscuros; trata-se de crença ou convicção (pístis). De modo que ainda há, entre estes dois planos, alguma confusão, uma imagem podendo ser tomada por um objeto e vice-versa. Ao passarmos à terceira seção da linha, a primeira do plano do inteligível, descobrimos que a alma pensa a partir de hipóteses, "utilizando, como se fossem imagens, as coisas anteriormente imitadas" (510B). O critério para distinguir a terceira da quarta seção é que, na última, não nos servimos mais de imagens, mas de Formas inteligíveis, procedendo rumo a um princípio não hipotético. Aqueles que se ocupam de geometria, por exemplo, servem-se de "formas visíveis" (tô̂s horoménois eídesi proskhrôntai) para fazer seus cálculos, pensando não exatamente nestas imagens, mas nas coisas às quais elas se assemelham (510D). O que me interessa indicar é que, ainda nesta primeira seção do 
inteligível (terceira da linha), recorremos a imagens: por um lado, tomamos os seres e objetos da segunda seção não mais como seres, mas como imagens dos objetos matemáticos, por exemplo; e os objetos inteligíveis da diánoia, como imagens de seres ou de relações inteligíveis. Não é que eles sejam meros reflexos por natureza, mas que eles são pensados, perante as Formas, como tais. Trata-se, como diz M. Dixsaut, de um uso "savant" da imagem, que a razão reconhece como tal, e de um uso insuficiente, ignorante da hipótese, ainda aceita como verdadeira (Dixsaut, [1980] 1986, p.98-105). Podemos então dizer que, neste sentido, a imagem passa a significar mais um modo de abordar as coisas, uma relação com elas, na medida em que a tomamos enquanto reflexo de outra coisa, semelhante mas diferente de algo mais inteligível que ela mesma. Na medida em que a diánoia também lida com imagens, podemos falar em imagens dianoéticas, com uma função decisiva no processo cognitivo das Formas, na medida em que as antecipam, preparando o caminho para sua apreensão.

Não só o filósofo, mas também o sofista, produtor de imagens, conta com essa capacidade de potencializar o desejo, pois há uma arte (tina állen tékhnen), que se ocupa dos discursos, que tem o poder de enfeitiçar os jovens ainda distantes da verdade das coisas, através de discursos vertidos nos seus ouvidos, que mostram imagens faladas de todas as coisas (édola legómena perì pánton). Esta arte tem o poder de fazer com que o que é dito pareça verdadeiro e com que aquele que fala pareça ser o mais sábio de todos os homens (234C2-7). Ela produz um efeito de verdade e um efeito de sabedoria; efeitos que concernem tanto ao próprio discurso, em seu poder próprio, digamos 'lógico', como àquele que o enuncia, em sua potência 'performativa' ou de produtor de aparências de verdade junto ao seu interlocutor. Como diz Glauco na República, "tudo aquilo que nos engana exerce uma magia sobre nós” (goeteúein pánta hósa apata) (República III 413C4) ${ }^{3}$. Sócrates explica que, ao falar dos homens submetidos à magia (toùs goeteuthéntas), ele quer designar todos aqueles que terão mudado de opinião e perdido a opinião reta, por terem sido envolvidos pelo prazer ou que a isto foram levados pelo medo, ou ainda, "aqueles que uma dor ou um sofrimento fez mudar de opinião" (hoùs àn odýne tis é algedòn metadoxásai poiése) (República III 413B9-10). A produção de imagens pelo discurso é sempre um meio eficaz de ação e de dominação do outro. Esta arte, produzida com habilidade, põe o produtor de imagens em uma posição de hábil (sábia?) superioridade e o interlocutor em posição de patética submissão.

Podemos dizer que, neste momento do diálogo, fica bastante claro, pela argumentação sinóptica que é feita, que o sofista pode ser envolvido pelo gênero do mágico, do imitador de coisas reais (hóti tôn goéton estí tis, mimetès òn tôn ónton), do gênero dos produtores de coisas espantosas (tôn thaumatopoiôn) (234E7-235B6). Resta estabelecê-lo diereticamente, isto é, pela divisão dos gêneros das artes. A reflexão sobre as aquisições das seis divisões anteriores leva, portanto, da antilogia à mimética, tornando possível estabelecer o ponto de partida para a sétima e última divisão do sofista: a divisão do gênero da arte da produção de imagens. Como é sabido, distinguem-se duas formas de mimética (he mimetiké). Por um lado, há a arte de produção de cópias (eikastiké), que leva em conta as proporções do modelo, sua largura, seu comprimento e sua profundidade; por outro lado, há a arte de produção de aparições ou simulacros (phantastiké), que não leva em conta as verdadeiras proporções dos modelos em suas obras, deixando de lado a verdade, pois realiza nas suas imagens não as proporções reais, mas as que parecem ser belas (Villela-Petit, 1991, p.55-90) ${ }^{4}$. 
A divisão da arte mimética, por sua vez, é interrompida para que se possa obter dialeticamente os elementos necessários para sua correta realização. O Estrangeiro e Teeteto interrompem a divisão dicotômica pois continuam na incerteza quanto a saber em qual das duas formas, produção de cópias ou produção de simulacros, devem incluir o sofista. Para que a caça ao sofista possa ser conduzida até o fim, deve-se poder demonstrar que a imagem é algo que é, e que o discurso falso é real, sem cair na contradição. Já foi mostrado que o sofista produz imagens verbais (eídola legómena) (234C5-6), mas ainda falta estabelecer referências que possam garantir a divisão do discurso em discurso verdadeiro e discurso falso, e assim subsumir a espécie do sofista sob o gênero do produtor de discursos-simulacros.

A potência de enfeitiçamento pela imagem e as questões que suscitam a reflexão sobre sua produção nos discursos são dificuldades que, ao solicitar a inteligência, exigem que sejam examinadas, o que faz progredir o diálogo. A caracterização da imagem como um ser aporético constituirá um passo fundamental no desenvolvimento do diálogo. Em última instância, a questão da produção da imagem só poderá ser compreendida no Sofista através da problemática da alteridade que aos poucos se depreende. O Estrangeiro estabelecerá a alteridade da imagem com relação àquilo de que ela é a imagem e retirará as consequiências para a produção do discurso falso, mas tudo isso será feito num contexto intensamente aporético, no qual se opõem os lógoi dos outros sábios, o que vai obrigá-lo a fazer um détour, a famosa "digressão ontológica", para que finalmente ele possa retomar a divisão da mimética.

\section{Aporia}

A aporia implica sempre uma incompatibilidade entre um lógos e outro (lógos sendo compreendido como argumento, tese ou discurso). A alteridade dos lógoi em aporia é antes de tudo a alteridade da contradição (ou da aparência de contradição). É esta impossibilidade de pôr os termos opostos em relação recíproca, de um modo ou de outro, que impede o movimento do lógos. Na aporia, a oposição entre os lógoi é compreendida de modo tal que se torna impossível continuar a pensar e a falar rigorosamente de modo concatenado. $\mathrm{O}$ sentido propriamente negativo da aporia é o do impasse, da impossibilidade que decorre das limitações do lógos em circunstâncias dialógicas precisas. É a aporia enquanto parada sobre o caminho. Neste sentido ela é uma descontinuidade que conduz a uma tomada de consciência da impotência do lógos. Mas se a aporia é negação e negativa com relação ao que é dito, ela é ao mesmo tempo fonte de afirmação que torna possível a continuidade do diálogo. A aporia é positiva no sentido que ela exige que a pesquisa dialética seja retomada em outras bases, na medida em que ela acaba por suscitar uma compreensão da alteridade que torna possíveis os verdadeiros e belos laços entre o ser, o mesmo e o outro. Como a imagem da maiêutica no Teeteto nos sugere (Teeteto 149A-C), a aporia é gênese na medida em que ela produz a autoconsciência naquele que se submete ao movimento do lógos; ela é produtora de lógos naquele que se deixa conduzir pela negação.

Nos diálogos em geral, Platão utiliza a imagem para trabalhar a aporia e fazer caminhar o discurso dialético. Basta evocar, a título de exemplo, as três imagens utilizadas em 
República VI e VII - o sol, a linha dividida e a caverna, e sua importância na abordagem do problema do Bem e no estabelecimento do que é a dialética como ciência suprema, na perspectiva da paidéia do governante-filósofo. O exame das situações aporéticas, recorrentes nos diálogos ${ }^{5}$, nos mostra que a imagem é muito mais do que mera ilustração do impasse, mas elemento constitutivo da trama argumentativa. O movimento do pensamento dialogado, sob o efeito da negatividade da interrupção, busca outros meios de se manifestar. Se ele pára, é para tentar explicitar o que ele busca através de outros meios. A passagem à imagem funciona como uma mediação entre a impossibilidade e a exigência de se continuar a pensar. A imagem na sua concretude e plurivocidade recebe os impasses dos lógoi em oposição, rearranja-os e oferece outros aspectos ao discernimento dos interlocutores. Através do jogo de intermediação operado pela imagem, entre os lógoi em oposição, o exame pode reencontrar seu movimento. A imagem acolhe as dificuldades ou as contradições que o lógos não consegue desdobrar e superar em um certo momento; o páthos da contradição é o que leva ao recurso à imagem; mas é ele também que exige sua superação, fazendo com que a investigação possa avançar. A imagem, pela sua equivocidade, recoloca em movimento algo que o lógos, em estado aporético, não consegue resolver. O que deve nos levar a reconhecer que, em Platão, o discurso conceptual e argumentativo não dispensa a narratividade própria à imagem; ele a assimila e a reconfigura, servindo-se dela no sentido de potencializar o próprio discurso.

No Sofista, algumas imagens fundamentais dominam a refutação dos discursos dos pensadores pré-platônicos a respeito do não-ser e do ser. A imagem do parricídio estrutura todo o diálogo. A imagem da esfera parmenídica será a fonte das aporias do ser, na sequiência do diálogo. A imagem do combate de gigantes serve a explicitar ainda outras aporias. Mas o mais importante é observar não apenas que as aporias são trabalhadas a partir da divisão da arte de produção de imagens, mas que o próprio estatuto ontológico da imagem é posto em questão, no núcleo central do diálogo, ligando de modo paradoxal o não-ser ao ser e exigindo que o discurso dialético ponha em questão discursos veneráveis e aceitos como verdadeiros. Dentre esses discursos, uns não reconhecem que há alteridade suficiente em torno do ser para que possamos dizer que ele não é, outros admitem que a única outra coisa que podemos ligar ao ser é o número, jamais o não-ser, a ponto de não podermos sequer pronunciar o termo 'não-ser'. Outros não reconhecem a alteridade entre coisa e imagem, deduzindo daí a impossibilidade do discurso falso.

A aporicidade própria da imagem é o que leva ao exame da condição mesma de possibilidade do discurso, que será compreendido como sendo fundado pelo entrelaçamento das Formas inteligíveis. A situação aporética é trabalhada metaforicamente, através da imagem do parricídio (241C7-242B5). A posição das aporias referentes ao não-ser e ao ser torna possível e necessária a formulação do problema do não-ser enquanto alteridade. Essas aporias resultam do impasse que consiste em afirmar aquele caminho que é um não-caminho em Parmênides. A aporia no Sofista é a explicitação necessária do que estava implícito no poema, a aporicidade inerente ao seu caráter compacto. Eé exatamente neste sentido que o poema estabelece o campo de forças no qual combaterão todos os discursos filosóficos a partir de Parmênides. Platão retoma o esquema mítico dos caminhos postos solenemente pela deusa, em toda a sua polissemia; ele explicita e desdobra suas possibilidades de signi- 
ficação, sempre resguardando os sentidos ético, lógico e ontológico implícitos no caminho (hodós) parmenídico. Poderíamos dizer que a aporia dialógica é a própria imagem parmenídica da encruzilhada de caminhos tornada conceito. E mais, em nosso diálogo, constatamos não apenas o recurso à imagem, mas a problematização da noção mesma de imagem, o que reforça sua caracterização como um diálogo intensamente auto-hetero-reflexivo.

A divisão da mimética é interrompida, pois há ainda incerteza quanto a saber em qual das duas formas deve-se inserir o sofista. Pois o sofista refugiou-se em uma forma cuja exploração é aporética (eis áporon eídos diereunésasthai) (236C9-D3). Da produção de imagens à produção do discurso falso, do "parecer e mostrar-se mas não ser" ao "dizer algo mas não dizer o verdadeiro" (236E1-3) (tò gàr phaínesthai toûto kaì tò dokeîn, eînai dè mè, kaì tò légein mèn átta, alethê dè me, pánta taûta esti mestà aporías), o que permite a passagem de uma problemática à outra é justamente aquilo que impede que haja passagem: a formulação aporética da ligação entre ser e não-ser implícita nas duas questões. Todas as duas implicam que é "aquilo que não é". Estamos no coração aporético do diálogo: como fazer ser o que não é? Como a imagem pode ser, não sendo o que ela pretende ser? Como o falso pode ser, sendo justamente aquilo que não é? Todo o problema está no "como encontrar um modo de dizer?" (hópos gar eipónta ...) (236E3-237A1). É a busca deste "como" que dirigirá a argumentação a partir deste ponto. Deve-se "dizer o como", para que se possa introduzir a necessidade naquilo que é aporético e dissolver assim a aparência de contradição. Na seqüência da argumentação, o Estrangeiro e Teeteto serão levados a pôr a hipótese segundo a qual o não-ser é, pois de outro modo, nem a imagem poderia tornar-se inteligível, nem o falso poderia tornar-se algo que é.

Eis que estamos presos, encantoados entre eleatas e sofistas ${ }^{6}$. A argumentação sofística contra a possibilidade do discurso falso, mesmo se às vezes parece não ser mais do que uma dissimulação mal intencionada, na verdade decorre diretamente da interdição do grande Parmênides que nos impede de continuar na direção que a divisão do sofista indica e nos impõe (236C 9 - 237B6). Ao fundar-se sobre uma tese eleata fundamental (a impossibilidade do não-ser), a discussão sofística da possibilidade mesma do discurso falso é mais do que um jogo erístico; para além da dissimulação, trata-se da exigência legítima de que a filosofia justifique sua pretensão de produzir o "discurso verdadeiro".

No Sofista, a questão da possibilidade do falso é abordada pelo viés das aporias derivadas das teses eleatas. Para que o falso seja algo que é, deve-se admitir que o não-ser é, o que havia sido proibido. A deusa parmenídica proíbe dizer que os não-seres são e impede que este entrelaçamento seja um caminho válido de pesquisa. Esse é seu testemunho. Mas, submeter-se a esta tese, simplesmente porque ela é a do pai significaria submeter-se a um argumento de autoridade, o que leva o Estrangeiro a propor que se ponha à prova o próprio argumento. O melhor testemunho é aquele que mostra a argumentação dialética. A argumentação que se segue, no texto do diálogo, consistirá em desenvolver uma série de aporias postas a partir da leitura platônica da interdição parmenídica. Uma série de aporias que só servem para pôr em evidência a impossibilidade de não matar Parmênides. O poema é de um caráter tal que ele transforma toda apropriação do discurso da deusa em traição, em distorção, ou mesmo em destruição. Desde Zenão, não cessamos de matar Parmênides; poderíamos até mesmo dizer que toda a história da filosofia não é mais do que uma série obsessiva de parricídios. Platão não foi o primeiro nem o último? 


\section{Imagem}

Após as três primeiras aporias relativas à possibilidade de dizer o não-ser ${ }^{8}$, numa perspectiva eleata ${ }^{9}$, aporias estas derivadas da posição inicial do problema da produção de imagens, o Estrangeiro e Teeteto formulam uma definição da imagem que, por sua vez, se apresentará como uma quarta aporia do não-ser (240A7-240C6). O problema inicial persiste: se o Estrangeiro e Teeteto não conseguem provar dialeticamente a possibilidade da arte da produção de simulacros (phantastiké), eles não poderão impedir o sofista de os contradizer.

Pois, tendo sido chamado de produtor de imagens, o sofista voltaria seus argumentos contra eles próprios: o que chamais, na verdade, de imagem (tí pote tò parápan eídolon légomen)? Como resposta à questão socrática do sofista, encarnado neste momento pelo Estrangeiro, Teeteto fala de imagens visíveis, aquelas que são produzidas fora da alma: sobre a água e sobre os espelhos, assim como as imagens pintadas ou esculpidas, e ainda tantas outras coisas do mesmo gênero (kaì tâlla hósa pou tiaût' esth' hétera) (239D9). Esta lista de imagens não constitui uma definição, pois ela funda-se sobre uma compreensão insuficiente da diferença que define alguma coisa. Teeteto confunde a questão relativa ao ser da imagem com a questão relativa aos seres que podem ser considerados imagens. Como em outras ocasiões nos diálogos, o interlocutor perde-se na alteridade aleatória e quantitativa da enumeração de coisas a definir, sem alcançar o nível que unifica todos seus caracteres essenciais em um lógos que diferencia a coisa daquilo que ela não é ${ }^{10}$. Esta resposta pareceria risível ao sofista, mas também ao Estrangeiro: o sofista invocaria o cego. É como se a imagem resistisse a se deixar circunscrever pelo discurso argumentativo. Face à pergunta pelo lógos da imagem, o jovem Teeteto, prisioneiro dela, enumera fenomenologicamente as diversas imagens que conhece pela experiência direta. A saída do Estrangeiro é a única possível. Ele faz um exercício de variação imaginária: ele nega a imagem enquanto dado imediato, para poder abrir o caminho para o estabelecimento de seu lógos, este sim, resultado de sucessivas mediações. O Estrangeiro força Teeteto a fazer um esforço para destacar a unidade a partir dos múltiplos exemplos citados:

240A7-8 T - Que poderíamos dizer, Estrangeiro, que é uma imagem, a não ser uma outra coisa parecida tornada semelhante ao que é verdadeiro?

A9-B1 E - Tu dizes que esta outra coisa parecida é verdadeira ou com relação a que tu dizes "parecida"?

2 T - Ela não é de modo algum verdadeira, mas semelhante.

3 E - Tu dizes que o verdadeiro é o que é realmente?

4 T - É assim.

5 E - E então? O não-verdadeiro é o contrário do verdadeiro?

6 T-Certamente.

7-8 E - Tu dizes que o que é semelhante é o que não é, se afirmas que ele é não verdadeiro. Entretanto ele é.

9 T - Como?

10 E - Pois bem, dizes que ele é verdadeiramente.

11 T - Certamente que não, a não ser que ele é realmente uma cópia.

12 E - Pois bem, aquilo que dizemos ser realmente uma cópia não é realmente?

C1-2 T - Pode ser que uma tal ligação entrelace o não-ser ao ser, e uma ligação estranha. 
3-5 E - Pois, como não seria ela estranha? Pelo menos, tu vês, ainda agora, graças a este entrelaçamento, que o sofista de múltiplas cabeças nos forçou a concordar, contra nós mesmos, que o não ser é, de algum modo.

6 T - Eu o vejo, e muito bem ${ }^{11}$.

Segundo Teeteto uma imagem é "uma outra coisa parecida tornada semelhante ao verdadeiro" (tò pròs talethinòn aphomoioménon héteron toioûton) (240A7-8). Esta outra coisa não é de modo algum verdadeira, mas semelhante. Se o verdadeiro é aquilo que é realmente; se o não-verdadeiro é o contrário do verdadeiro, e se o semelhante é não-verdadeiro, então o que é semelhante é o que não é. Entretanto, ele é: não verdadeiramente, mas realmente uma cópia. O que é realmente uma cópia, não é realmente. Eis nossa aporia. A questão relativa ao que é a imagem retoma o ponto de partida do exame dialético, pois a imagem contém não-ser; não se pode explicar o que é a imagem sem dizer o que se compreende por não-ser. O sofista os forçou rumo a um estranho entrelaçamento do não-ser ao ser. De um certo modo o não-ser é, quer dizer, enquanto imagem ${ }^{12}$.

Temos assim os elementos que definem o caráter da imagem, segundo Teeteto: a alteridade e a semelhança. É este caráter duplo que faz com que uma coisa possa (a)parecer sem ser o que ela parece ser. O que, transposto ao problema do lógos, significa levantar o problema da falsidade: como é possível dizer alguma coisa sem dizer o verdadeiro? ${ }^{13}$. A aparência sem ser é análoga ao discurso sem verdade. A formulação discursiva do ser da imagem é aporética nela mesma: o ser do que não é o ser que ele representa, o ser do que não é. Por analogia, chegamos à aporia do dizer alguma coisa sem dizer algo verdadeiro, a questão do dizer o que não é, que será a quinta aporia do não-ser (240C7-241C6).

O próprio fato de enunciar o problema do discurso falso conduzirá mais uma vez à contradição. O sofista produz aparências de contradição porque ele não se funda sobre o ser inteligível daquilo sobre o que ele acredita contradizer. Para que possamos ultrapassá-lo devemos estabelecer o modo como compreendemos a alteridade dos lógoi em oposição. Em última instância, a solução proposta pelo Estrangeiro visa não apenas a imagem mas o próprio discurso, o que implicará na posição da forma inteligível do outro. De qualquer modo, devemos ser capazes de reconhecer uma verdadeira contradição, pois só assim poderemos mostrar que o que faz o sofista não são contradições, mas aparências de contradições. Se buscamos apenas o efeito que a aparência de contradição produz no outro, não há perigo: basta "contradizer" ao nível das palavras, ao nível do que chamo de alteridade aleatória. Entretanto, para o Estrangeiro, filósofo caçador de sofistas, o caminho está repleto de perigos: ele quer caçar o caçador de jovens, ele visa estabelecer que a verdadeira contradição é possível, que não podemos contradizer de maneira aleatória e, ainda por cima, ele mesmo não pode cair em contradição.

Ora, há contradição quando, reunindo as opiniões aos discursos, os interlocutores confrontam-nos uns com os outros, face ao mesmo (com o mesmo argumento), e, ao confrontá-los eles demonstram que elas, as opiniões, são contrárias a elas mesmas, ao mesmo tempo, no que concerne aos mesmos aspectos, com relação às mesmas coisas, no mesmo sentido (... sunágontes dè tồs lógois eis tautòn tithéasi par'allélas, tithéntes dè epideiknúousin autàs hautaîs háma perì tôn autôn pròs tà autà katà tautà enantias - 230B68). Portanto há contradição quando algo é tomado como sendo e não sendo, ao mesmo tempo, no mesmo sentido. Para dissolvê-la deve-se mostrar que alguma coisa que é em um 
sentido, não pode não ser no mesmo sentido. Ou ainda que, se ela é de um certo modo, para que ela não seja, é necessário que ela seja tomada em outro modo de ser. É necessário que uma mesma coisa possa ser visada, em diferentes momentos, em seus modos diferentes de ser, para que ela possa ser e não ser tudo o que ela é e tudo o que ela não é. Por um lado, para mostrar que o refúgio sofístico não é mais do que uma aparência de contradição, deve-se mostrar que há alteridade lá onde acreditávamos que só havia identidade. Por outro lado, para a pretensão filosófica do Estrangeiro de fundar firmemente todo discurso e deste modo as Musas e a Filosofia, deve-se ir mais longe ainda, mas isto só será possível pela introdução do não-ser como uma parte da forma inteligível do outro.

O não-ser poderia significar “aquilo que absolutamente não é”, e Parmênides teria razão, e com ele o uso sofístico da interdição da deusa. O não-ser absoluto permaneceria impensável e indizível. Não haveria o parricídio. Mas o não-ser pode também significar o que não é em um certo sentido, de um certo modo, um não-ser relativo. Ele significaria, nesta perspectiva, 'aquilo que é outro que', sem que a coisa que não é seja ameaçada em sua integridade, sem que ela perca seu ser-mesma-que-ela-mesma. Algo não é na medida em que é outro que alguma outra coisa. O pai é morto. O sofista, justamente ao parecer contradizer todos e em todos os momentos, dissolve a contradição. Por outro lado, estabelecer a possibilidade da contradição significa estabelecer que o discurso pode ser verdadeiro ou falso, e que ele é falso quando ele é verdadeiramente contraditório. A solução última do filósofo no Sofista consistirá em mostrar que estas relações devem ser reguladas ontologicamente pelo entrelaçamento do não-ser ao ser, tornado possível pela forma do outro.

Ora, a imagem é este ser que reúne em seu modo de ser justamente os elementos necessários para formular o problema do discurso falso e da contradição: o discurso falso é algo que não é justamente aquilo que ele pretende ser. A imagem é esta aparência de contradição tornada tangível. É porque o Estrangeiro quer estabelecer o discurso falso que é necessário tornar possível a imagem, mostrar que ela é e que ela só é contraditória em aparência, que o discurso é possível enquanto uma de suas espécies e que ele só é falso quando confunde o que é mesmo com o que é outro.

Poderíamos ser tentados a crer que a analogia não é feita entre a imagem visual e a imagem verbal (o discurso), por um lado, e entre a imagem que distorce e o discurso falso, por outro lado, mas entre a imagem e o discurso falso. Em seu exame, o Estrangeiro parece confundir uma diferença de natureza, aquela que existe entre o modelo e sua imagem, com uma diferença de qualidade, aquela que existe entre a imagem "verdadeira" (a cópia, o discurso verdadeiro) e a imagem que altera (o simulacro, o discurso falso). Entretanto, para o Estrangeiro, na realidade, o discurso também é outro que a coisa ${ }^{14}$. Sendo outro, por natureza, o discurso, no seu modo de representar aquilo com relação ao qual ele é outro, assim como a imagem visual, pode dizer do mesmo que ele é mesmo e do outro que ele é outro, dizendo o verdadeiro, ou ainda, dizer do mesmo que ele é outro, ou do outro que ele é mesmo, dizendo o falso. Mas neste momento do diálogo, mesmo se o Estrangeiro já se diferencia de Parmênides, o que importa é formular a aporia que decorre da visão parmenídica. Retrospectivamente, poderíamos dizer que para Parmênides, a imagem verdadeira não é outra que a coisa, o que nos daria o seguinte esquema: a coisa confunde-se com a imagem 
verdadeira, todas as duas opondo-se à imagem enquanto tal, que seria o mesmo que a imagem falsa. Mas, como nos é mostrado no Crátilo (432B-C), Platão quer impor outros critérios para além da semelhança para compreender o ser da imagem verbal, o ser do discurso. A analogia com a imagem visual, que, ela sim, é fundada sobre a semelhança, não é suficiente para dar conta do discurso falso, ela só é o ponto de partida da análise. É necessário que o critério da semelhança, tomado emprestado ao domínio das imagens visuais, seja ultrapassado em favor de um critério mais adequado à especificidade das imagens verbais, ao lógos, que pretende dizer das coisas sua realidade inteligível. O lógos representa de um outro modo, e é com relação a mas contra a semelhança das imagens visuais que poderemos determiná-lo. Ao estabelecer a imagem como outra, alguma coisa outra que aquilo que é, e, ainda, num segundo momento, ao considerar a imagem como podendo ser outra que o que é verdadeiro, o Estrangeiro agarra o sofista ali mesmo onde ele acreditava poder esconderse. Para poder falar das relações entre imagem e coisa, devemos antes de tudo aceitar sua alteridade, o que desconcerta eleatas e sofistas.

Se na aporia a analogia é feita entre a imagem e o discurso falso, não é porque o Estrangeiro toma a alteridade como sendo falsidade. Para o Estrangeiro, a imagem não é falsa porque ela é outra que a coisa. Para Platão, isso é eleatismo. Numa perspectiva eleata, a "falsidade" integra a natureza da imagem no sentido em que é sua alteridade que torna possível seu modo (falso) de representar a coisa. Não há alteridade suficiente para que haja um ser da imagem, nem sequer para que possamos fazer uma analogia. É o Estrangeiro que propõe a analogia, mas ele o faz em termos parmenídicos justamente para constituir a aporia, e ele só a resolve de fato no final do diálogo, quando retoma a última divisão, após ter realizado o parricídio, após ter estabelecido o não-ser como parte da forma do outro. É sendo o que ela não é que a imagem pode ser análoga ao discurso falso, mas, após a análise das ligações entre as formas, este entrelaçamento não será mais contraditório. Só então o ser da imagem poderá ser legitimamente o ser do que não é.

$\mathrm{O}$ critério que ultrapassa a semelhança, na perspectiva platônica é a significação. $\mathrm{O}$ discurso não mostra tornando-se semelhante a alguma coisa, mas realizando alguma coisa (peraínein tì), significando. A significação de um discurso será formulada nos termos das ligações inteligíveis que as formas estabelecem entre elas; só estas ligações inteligíveis podem torná-lo significante.

Como foi indicado, nas passagens aporéticas do Sofista, encontramos não apenas a dificuldade de pensar e de falar em uma circunstância dada (aporía), mas a discussão radical das próprias condições de possibilidade do pensamento e do discurso ou de sua fundamentação ontológica. Ao tornar manifesto o caráter dialético da aporia, através da reflexão sobre a imagem, descobrimos a aporicidade estrutural do pensamento e do discurso humanos. Para enfrentar o espanto provocado pela antilogia e pela atopia da imagem, para atravessar o páthos da aporia, os interlocutores têm que se submeter a um certo modo de dialogar, ao caminho dialético, o único que permite que o lógos verdadeiro se mostre, de uma aporia à outra, como um caminho que persiste.

A produção de imagens, pelo artista, pelo sofista e pelo filósofo é um tema antropológico que suscita a questão do estatuto ontológico da imagem. O enfeitiçamento pela imagem, obstáculo decisivo para a constituição de uma paideía política (República), é enfrentado, 
no Sofista, radicalmente, isto é, nos termos mesmos de sua possibilidade última. É esta exigência de radicalidade que leva o Platão da velhice a aprofundar sua ontologia, num embate com Parmênides. É muito significativo que as páginas mais pungentes da ontologia platônica situem seu núcleo reflexivo no problema da imagem, enquanto aporia a ser desmistificada argumentativamente. Também vítima do fascínio da imagem, o filósofo esforça-se por dar conta dela, lança mão de todos os seus recursos argumentativos para circunscrevê-la, para elucidá-la enquanto problema teórico e racional. Longe de querer livrar-se da imagem, uma tarefa absurda (ele também é um produtor de imagens), o filósofo pergunta pelo seu ser, explicita sua aporicidade e remete-a ao plano da ligação entre as formas onde, apenas através da formulação de uma participação regulada pela alteridade inteligível, a imagem poderá ter seu fascínio desvendado, pelo menos parcialmente, enquanto ser daquilo que não é.

\section{Notas}

1 - Dedico este trabalho à imagem do Senhor Bom Jesus dos Passos, que povoou e assombrou minha infância em Passos, MG, minha cidade natal.

2 - Na quarta aporia do não-ser, a imagem será definida como "uma outra coisa parecida, feita à semelhança do que é" (240A7-C6). Ver, abaixo, seção 3.

3 -Podemos ainda perceber aqui a ressonância da potência mítica do Engano ('A $\pi \alpha ́ \tau \eta)$. Cf. Detienne, 1981.

4 - Villela-Petit (1991) remete esta distinção conceitual ao contexto cultural da evolução das artes plásticas em Atenas na época de Platão. Platão extrai esta distinção da prática efetiva dos artistas de sua época. O gênero da "produção de cópias" traduz a fabricação de imagens referida a um modelo geométrico, idealizante. O gênero "produção de simulacros", por sua vez, tenta compreender a novidade que significa a fabricação de imagens que prioriza antes o ponto de vista do observador, visando produzir nele um efeito de verossimilhança.

5 -Alguns exemplos: Eutifron 11B1-D6 - Dédalo; Górgias 521C7-522C8 - o médico; Menon 79D7-80D - a raia elétrica; Teeteto 145D4-146BB - as crianças; Teeteto 148D4-151D6 - a maiêutica; Parmênides 130C1-E4 - o abismo; Parmênides 133A10-134D - o senhor e o escravo; Leis VII 799C4-E7 - o cruzamento, o caçador e o sonho, etc.

6-Ver Teeteto 180C7-181A4, onde, a propósito da oposição movimento-repouso, Sócrates reconhece "que eles caíram no meio de dois campos" - eis tò méson peptokótes.

7-O que faz de nós todos (nós, leitores de Parmênides) parricidas tem a ver com as dificuldades de nos apropriarmos de um discurso essencialmente ambíguo, um discurso poema que se constitui entre o relato mítico e o discurso argumentativo. Cf. Marques, 1991, p.18-19; 30-38.

8 - (1) 237B7-E7 - O não-ser tomado como predicado (2) 238A1-C12 - O não-ser tomado como sujeito (3) 238D1-239C8 - Da irrefutabilidade do não-ser. Cf. Movia, 1991, p.230, n.49; Rosen, 1983, p. 182.

9-É importante compreender que as aporias são postas dentro do contexto de uma ontologia eleata: é para o sofista, ou para Parmênides, que dizer o não-ser significa não dizer nada, não para o Estrangeiro, ou para Platão.

10 - Cf. República VI 510A; Teeteto 146C; ver também Dixsaut, 1994, p.326.

11 - Sofista 240A7-C6, segundo as lições dos manuscritos T e Y, conforme o texto proposto por N. L. Cordero: 


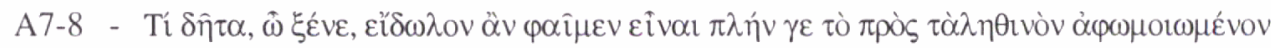

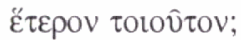

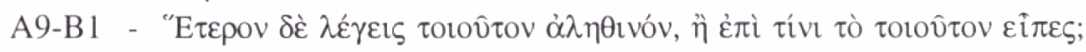





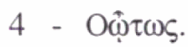



6 - Tí $\mu$ ńv.

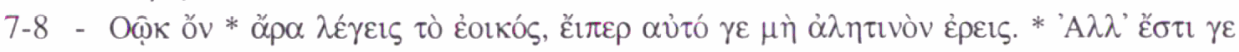
$\mu \eta \dot{v}$.

9 - $\Pi \hat{\omega} \xi ;$

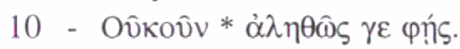



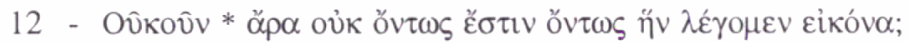

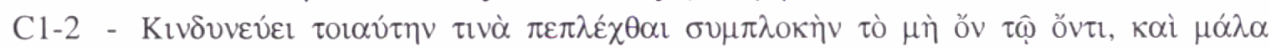

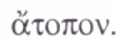



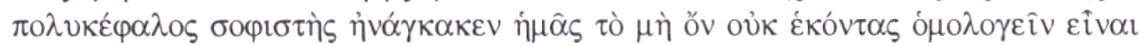
$\pi \omega \zeta$.



O estabelecimento do texto dessa passagem é muito controverso, do ponto de vista filológico. $\mathrm{Na}$ minha tradução aceito o estabelecimento proposto por N.-L. Cordero (1993). Este tradutor segue, para essa passagem, as lições dos manuscritos T (Venetus, Ap. Class. 4,1) e Y (Vindobonensis 21), já seguidas por Marsilio Ficino, em 1482. T é o codex mais antigo; sua data foi recentemente recuada do séc. XII ao séc. IX, pela identificação de seu copista. Os textos de T e Y foram seguidos tanto por Aldo Manuce (Veneza, 1513) como por Henricus Stephanus (Genova, 1578), assim como por todos os editores até a metade do séc. XIX. Em T e Y, para as linhas 240B7-8, temos "ouk òn ára légeis tò eoikós ..." - "Tu dizes que o que é semelhante não é". Quanto aos outros manuscritos, B (Bodleianus Clarkianus, séc. IX) e W (Vindobonensis 54, Sup. gr. 7), perfeitamente confiáveis no geral, Cordero recusa-os pelas razões que resumo a seguir (Cordero, 1993, Anexo II, p.288-290). Na passagem em questão, 240B7-8, o texto de B está corrompido, e temos "ouk ónton (gen. pl.) ouk ón". O manuscrito W, que foi descoberto por Bast em 1794, apresenta uma leitura com duas negações - "ouk óntos (adv.) ouk ón". Em 1851, C. F. Hermann publica em Leipzig uma edição do Sofista, utilizando, pela primeira vez, o texto de W. Acontece que, a partir desta data, todas as edições passaram a adotar sua solução. Como explica Cordero, trata-se de um caso de ditografia, no qual o copista, preocupado em registrar as diferenças entre os manuscritos, anotava duas versões do mesmo texto. Nesta linha, o copista pegou ouk óntos de uma fonte e ouk ón de outra e os copiou um após o outro, fazendo da imagem "um irreal não ser" (leitura e tradução adotadas por Diès na edição da C. U. F). Esta tradução, baseada no estabelecimento problemático do texto, está subjacente às interpretações, por exemplo, de J.-P. Vernant, em seus artigos sobre a imagem e o duplo na Grécia antiga e em Platão. Ver crítica de Desclos a Vernant em Desclos, 2000, p.301-312.

12 - Eis como alguns comentadores traduzem nossa aporia, tentando encontrar uma solução: segundo R. S. Bluck, na frase "a imagem não é", o ser é o ser de identidade, a imagem não é o mesmo que, ela é outra que. Na frase "a imagem é", os sentidos existencial e copulativo não são dissociados. "The solution which the EV eventually finds is to isolate the 'is' which expresses identity, and then to show that 'is not' can express non-identity, meaning is other than”. Bluck, 1975, p.66. Segundo Movia, "Certamente, la copia x non è l'oggetto vero X di 
cui è una copia; che "x è x e, al tempo stesso, non è y" non è autocontraddittorio". Movia, 1991, p.235.

13 - A imagem é, portanto, o centro de uma rede de aporias que desafiam filósofos e comentadores. F. M. Cornford interpreta esta passagem através da teoria dos "graus de realidade": as imagens constituem uma terceira região intermediária, a região das coisas que não são nem inteiramente reais, nem inteiramente não-existentes. "It is something that has some sort of existence without being wholly real". Cornford, 1935, p. 210-212. Por outro lado, segundo R. S. Bluck, o único problema aquí é o de dizer como alguma coisa que não é alguma outra coisa pode ser ela mesma. O "esti pos" não significa que a cópia existe apenas em um grau limitado, mas que ela tem ser de um certo modo, a saber, que ela não é o original. Bluck, 1975, p.66-68.

14 - Três argumentos: 1. A partir da análise da imagem, enquanto outra mas semelhante ao que é verdadeiro, portanto, sendo outra que aquilo de que ela é a imagem (240A), o discurso também é pensado como sendo outro que aquilo de que é o discurso, para que seja possível pensar o discurso falso. 2. Na refutação dos monistas, para o Estrangeiro, o nome é outro que aquilo que ele afirma. O nome não pode ser idêntico à coisa da qual é o nome, pois ele seria nome de nada. Para que ele seja nome de algo, ele deve ser nome de algo outro que ele mesmo (244D-E). 3. Finalmente, na refutação dos "velhos que começam tarde", a discussão implica, igualmente, que, segundo o Estrangeiro, o discurso é outro que a coisa. Quando se fala em enunciar algo, parece claro que alguém só enuncia na medida em que aquilo que ele enuncia não coincide com aquilo através do que algo é enunciado, e que a coisa visada é tornada manifesta por intermédio do nome (251B-C, tese; 252B-C, refutação).

\section{Referências bibliográficas}

\section{Textos:}

Platonis Opera, recognovit brevique adnotatione critica instrvxit Ioannes Burnet, Tomes I-V. Oxford: Clarendon Press, 1900-1907.

Platonis Opera - T.I tetralogias I-II continens [insunt Euthyphro, Apologia, Crito, Phaedo, Cratylus, Theaetetus, Sophista, Politicus], recognoverunt brevique adnotatione critica instruxerunt W.A. Duke, W.F. Hicken, W.S.M. Nicoll, D.B. Robinson et J.C.G. Strachan. Oxford: Oxford Clarendon Press, 1995.

PLATON. République. Livres VI et VII. Trad. de M. Disxaut. Paris: Bordas, 1986.

. Sophiste. Trad. de N.-L. Cordero. Paris: GF - Flammarion, 1993.

. République. Trad. de P. Pachet. Paris: Gallimard, 1993.

Théétète. Trad. de M. Narcy. Paris: GF - Flammarion, 1994.

. Cratyle. Trad. de C. Dalimier. Paris: GF-Flammarion, 1998.

Tutti gli scritti. A cura di G. Reale. Gli scriti di Platone sono traduti, presentati e annotati da: Reale, G.; Gatti, M.L.; Mazzarelli, C.; Migliori, M.; Liminta, M.T.; Radice, R. Milano: Rusconi Libri, (1991) 1994.

Plato's theory of knowledge. The Theaetetus and the Sophist of Plato. Translated with a running commentary by F. M. Cornford. London: Kegan Paul, Trech, Trubner. New York: Harcourt, Brace, 1935. 


\section{Obras gerais:}

AUBEnQUE, P. (Dir.) Etudes sur Parménide. Tome I. Le poème de Parménide. texte, traduction et essai critique par D. O’Brien; J. Frère. Paris: Vrin, 1987.

AUBENQUE, Pierre. (Dir.) Etudes sur le Sophiste de Platon. Napoli: Bibliopolis, 1991.

BLUCK, R.S. Plato's Sophist, a commentary. Manchester: G.C.Neal Ed., 1975.

CANTO-SPERBER, M. Dictionaire d'Ethique et de Philosophie Morale. Paris: P.U.F., 1997.

CASSIN, B. L'effet sophistique. Paris: Gallimard, 1995.

DESCLOS, M.-L. Idoles, îcones et phantasmes dans les dialogues de Platon. Revue de Métaphysique et de Morale 3 (2000) p.301-327.

DETIENNE, M. Les Maîtres de la Verité dans la Gréce Archaïque. Paris: Maspero, 1981.

DIXSAUT, M. Platon. République. Livres VI et VII. Paris: Bordas, (1980) 1986.

. Le naturel philosophe. Essai sur les dialogues de Platon. Paris: Les Belles, (1985) p.1994.

Platon et le logos de Parménide. In: Aubenque, P. (Dir) Etudes sur Parménide, II. Paris: Vrin, 1987, p.215-253.

FESTUGIERE, A. J. Etudes de philosophie grecque. Paris: Vrin, 1971.

FREDE, M. Bemerkungen zum Text der Aporienpassage in Platons Sophistes. Phronesis 7 (1962) p.132-135.

FRÈRE, J. Les grecs et le désir de l'Être. Paris: Les Belles Lettres, 1981.

MARQUES, M. P. O Caminho Poético de Parmênides. São Paulo: Loyola, 1991.

MOVIA, Giancarlo. Apparenze, essere e vertità. Milano: Vita e Pensiero, 1991.

PALUMBO, L. Il non essere e l'apparenza. Sul Sofista di Platone. Napoli: Loffredo Ed., 1994.

Sulla nozione di phántasma nel Sofista platonico. Atti della Accademia di Scienze Morali e Politiche di Napoli (1990) p.23-42.

ROSEN, Stanley. Plato's Sophist. The drama of original and image. New Haven/London: YUP, 1983.

VERNANT, J-P. Image et apparence dans la théorie platonicienne de la mimesis. Journal de Psychologie Normale et Pathologique 62 (1975) p.133-160.

VILLELA-PETIT, M. La question de l'image artistique dans le Sophiste. In: Aubenque, P. (Dir.) Etudes sur le Sophiste de Platon. Napoli: Bibliopolis, 1991, p.53-90.

MARQUES, M. P. Image and aporia in Plato's Sophist. Classica. São Paulo, 13/14, p. 189$204,2000 / 2001$.

ABSTRACT: It is in the context of the series of aporiai related to the possibility of saying what is not, in an eleatic perspective, aporiai which result from the initial position of the problem of the 
production of images, that que Eleatic Stranger and Theaetetus formulate a definition of image which constitutes an aporia of non-being. My purpose in this paper is to understand the problem of image in the Sophist by revealing its connections with the theme of production (anthropological level) and with that of aporia (logical and ontological levels).

KEYWORDS: Plato; sophist; image; aporia. 